\title{
Distribution, possible sources, and health risk assessment of SVOC pollution in small streams in Pearl River Delta, China
}

\author{
Hongwei Sun • Taicheng An • Guiying Li • Meng Qiao • \\ Dongbin Wei
}

Received: 16 November 2013 / Accepted: 12 May 2014 / Published online: 28 May 2014

(C) Springer-Verlag Berlin Heidelberg 2014

\begin{abstract}
The pollution levels of typical semivolatile organic compounds (SVOCs) consisting of 15 polycyclic aromatic hydrocarbons (PAHs), 20 organic chlorinated pesticides (OCPs), and 15 phthalate esters (PAEs) were investigated in small rivers running through the flourishing cities in Pearl River Delta region, China. The concentrations of $\sum 15$ PAHs were $2.0-48 \mathrm{ng} / \mathrm{L}$ and $29-1.2 \times 10^{3} \mathrm{ng} / \mathrm{g}$ in the water and sediment samples, respectively. The $\sum 200 \mathrm{CPs}$ were $6.6-$ $57 \mathrm{ng} / \mathrm{L}$ and $9.3-6.0 \times 10^{2} \mathrm{ng} / \mathrm{g}$ in the water and sediment samples, respectively. The concentrations of $\sum 15$ PAEs were much higher both in the water and sediments. The partition process of the detected SVOCs between the water and sediment did not reach the equilibrium state at most of the sites when sampling. The combustion of petroleum products and coal was the major source of the detected PAHs. The OCPs were mainly historical residue, whereas the new inputs of dichlorodiphenyltrichloroethane (DDT), chlordane, and endosulfan were possible at several sites. The industrial and
\end{abstract}

Responsible editor: Roland Kallenborn

Electronic supplementary material The online version of this article (doi:10.1007/s11356-014-3031-4) contains supplementary material, which is available to authorized users.

H. Sun · T. An · G. Li $(\bowtie) \cdot$ M. Qiao

The State Key Laboratory of Organic Geochemistry and Guangdong Key Laboratory of Environmental Protection and Resources

Utilization, Guangzhou Institute of Geochemistry, Chinese Academy of Sciences, Guangzhou 510640, China

e-mail: ligy1999@gig.ac.cn

M. Qiao $\cdot$ D. Wei $(\varangle)$

Research Center for Eco-Environmental Sciences, Chinese Academy of Sciences, Beijing 100085, China

e-mail: weidb@rcees.ac.cn

H. Sun • M. Qiao

University of Chinese Academy of Sciences, Beijing 100049, China domestic sewage were the major source for the PAEs; storm water runoff accelerated the input of PAEs. No chronic risk of the SVOCs was identified by a health risk assessment through daily water consumption, except for the $\sum 20 \mathrm{OCPs}$ that might cause cancer at several sites. Nevertheless, the integrated health risk of the SVOCs should not be neglected and need intensive investigations.

Keywords SVOCs $\cdot$ PAHs $\cdot$ OCPs $\cdot$ PAEs $\cdot$ Source identification $\cdot$ Health risk

\section{Introduction}

In the past several decades, the Pearl River Delta (PRD) region in southern China has experienced rapid industrial development and urbanization, causing significant environmental problems. Among various contaminants, semivolatile organic compounds (SVOCs) have drawn much attention because they are highly toxic and long-distance transportable, and some of them such as organic chloride pesticides (OCPs) are recalcitrant to natural degradation. Besides, most of SVOCs are lipophilic and bioaccumulative, which increase the risk to human exposure (Jones and de Voogt 1999; Lohmann et al. 2007; Cai et al. 2008). In 2001, the Stockholm Convention defined 12 SVOCs as persistent organic pollutants (POPs) including nine OCPs (UNEP 2001). Sixteen polycyclic aromatic hydrocarbons (PAHs) are regulated as priority environmental pollutants by the US Environment Protection Agency (USEPA), among which seven PAHs were found to be carcinogenic in experimental animals (Jiang et al. 2009). Phthalate esters (PAEs), another type of SVOCs, are primarily applied as plasticizers in polymers, accounting for $10-60 \%$ of the total plastics by weight (Zeng et al. 2008). Diisobutyl phthalate (DiBP) has been reported to disrupt endocrine and impair reproductive development of male rat (Saillenfait et al. 2008). 
Further, di(2-ethylhexyl) phthalate (DEHP) is classified as a probable carcinogen by the USEPA.

SVOCs such as PAHs and OCPs have been frequently detected in the PRD region (Guo et al. 2008; An et al. 2011; Feng et al. 2012), whereas the small rivers in this region have not been investigated. Compared to the main river, the small rivers are more closely connected to the pollution sources and weaker in self-cleaning capacity. The contaminated local streams bother the residents with dark appearance and unpleasant smell; moreover, they also pose hazardous risk to human health. In this study, the contamination levels of SVOCs such as PAHs, OCPs, and PAEs in local small streams within the PRD region were determined. In addition, the phase partition behaviors and possible input sources of the SVOCs were investigated to elucidate the environmental behavior and fate of the detected contaminants. Finally, a preliminary study on the effects of the detected contaminants on human health through water consumption was conducted using the exposure model and health risk parameters established by the USEPA and the European Food Safety Authority (EFSA) to estimate whether or not the water was safe for drinking.

\section{Materials and methods}

\section{Materials}

Standards solutions for the quantification and quality control experiments were purchased as described in our previous report (Li et al. 2013). The 15 PAH standards were acenaphthylene (Ace), acenaphthene (Dih), fluorene (Flu), phenanthrene (Phe), anthracene (Ant), fluoranthene (Flua), pyrene (Pyr), benzo $[a]$ anthracene $(\mathrm{B} a \mathrm{~A})$, chrysene (Chry), benzo $[b]$ fluoranthene $(\mathrm{B} b \mathrm{~F})$, benzo[ $k]$ fluoranthene $(\mathrm{B} k \mathrm{~F})$, benzo $[a]$ pyrene (BaP), indeno[1,2,3-cd]pyrene (IncdP), dibenz $[a, h]$ anthracene $(\mathrm{D} i \mathrm{~B})$, and benzo[ $g, h, i]$ perylene $(\mathrm{B} g h i \mathrm{P})$. Surrogate standards consist of four deuterated PAHs such as acenaphthylene-d10, phenanthrene-d10, chrysene-d12, and perylene-d12. The 20 OCP standards were $\alpha$ hexachlorocyclohexane $(\alpha-\mathrm{HCH}), \beta$-hexachlorocyclohexane $(\beta-\mathrm{HCH}), \gamma$-hexachlorocyclohexane $(\gamma-\mathrm{HCH}), \delta-$ hexachlorocyclohexane $(\delta-\mathrm{HCH}), p, p^{\prime}-$ dichlorodiphenyldichloroethane $\left(p, p^{\prime}\right.$-DDD), $p, p^{\prime}$ dichlorodiphenyldichloroethylene ( $p, p^{\prime}$-DDE), $p, p^{\prime}$-dichlorodiphenyltrichloroethane ( $p, p^{\prime}$-DDT), $\alpha$-chlordane, $\gamma$ chlordane, heptachlor (Heptach), heptachlor epoxide (Hepch epo), $\alpha$-endosulfan, $\beta$-endosulfan, endosulfan sulfate, aldrin, dieldrin, endrin, endrin aldehyde, endrin ketone, and methoxychlor. Surrogate standards for OCPs were 2,4,5,6-tetrachloro- $m$ -

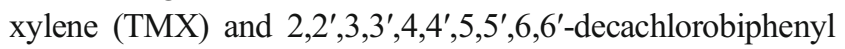
(PCB209). The 15 PAE standards were dimethyl phthalate (DMP), diethylphthalate (DEP), diisobutyl phthalate (DiBP), dibutylphthalate (DnBP), bis(4-methyl-2-pentyl)
phthalate(BMPP), bis(2-ethoxyethyl) phthalate (BEEP), diamyl phthalate (DAP), dihexyl phthalate (DHP), butylbenzyl phthalate (BBP), bis(2-methoxyethyl)phthalate (BMEP), bis(2butoxyethyl) phthalate (BBEP), dicyclohexyl phthalate (DCHP), di(2-ethylhexyl) phthalate (DEHP), dinonyl phthalate(DnNP), and dioctyl phthalate (DnOP). Diphenyl phthalate (DphP) was adopted as the surrogate for the PAEs according to USEPA method 8061A. Hexamethylbenzene (HMB) was used as the internal standard except for the OCP quantification, where pentachloronitrobenzene (PCNB) was applied. All the solvents used were of HPLC grade or redistilled analytical grade. The details of the materials involved and pretreatment methods are provided in the electronic supplementary material 1 (ESM 1).

\section{Study site and sampling}

Six sampling sites were chosen as shown in Fig. 1. Sites S1 and S2 were in suburban areas, and site S3 was near a canal in downtown. Sites S5 and S6 were beside industrial areas, whereas site S4 was in a rural area. For each site, the water and sediment samples were collected during both dry (December 2008) and wet (July 2009) seasons. Two clean amber glass bottles with glass caps of $10 \mathrm{~L}$ volume was rinsed twice with water samples and filled, leaving no headspace air. The collected water samples were transported to the laboratory as soon as possible and filtered through prebaked glass microfiber filters (GF/Fs, $142 \mathrm{~mm}$ in diameter, Whatman, England) to remove suspended particles immediately. The filtrate was stored at $4{ }^{\circ} \mathrm{C}$ and further pretreated within 3 days. The sediment samples were collected from the riverbed surface (with depth $<20 \mathrm{~cm}$ ) with stainless steel sediment sampler and held in stainless steel jars to avoid contamination of PAEs. After shipped to the laboratory, the sediments were freeze-dried; homogenized by grinding after removing sundries such as stones, leaves, and garbage; and passed through an 80-mesh stainless steel sieve. The sieved sediments were stored at $-20{ }^{\circ} \mathrm{C}$ before the extraction. The details of sampling can be found in Table S1 in the ESM 1.

\section{Pretreatment procedure}

Sample extraction and purification were carried out according to our previous study (Qiao et al. 2010). The water samples were filtered, spiked with the surrogate standards, and then passed through the XAD-2 resin columns (Supelco, Bellefonte, USA) to adsorb the SVOCs. The adsorbed organics were eluted using $40 \mathrm{~mL}$ of a mixture (methanol/ dichloromethane $(\mathrm{DCM})=80: 20)$ for four times. The eluent mixture was successively extracted with a mixture of DCM and saturated sodium chloride solution and DCM and deionized water. The DCM fractions were combined and evaporated to $10 \mathrm{~mL}$, and the solvent was exchanged with hexane. Next, the sample was concentrated to $1 \mathrm{~mL}$ and purified using 


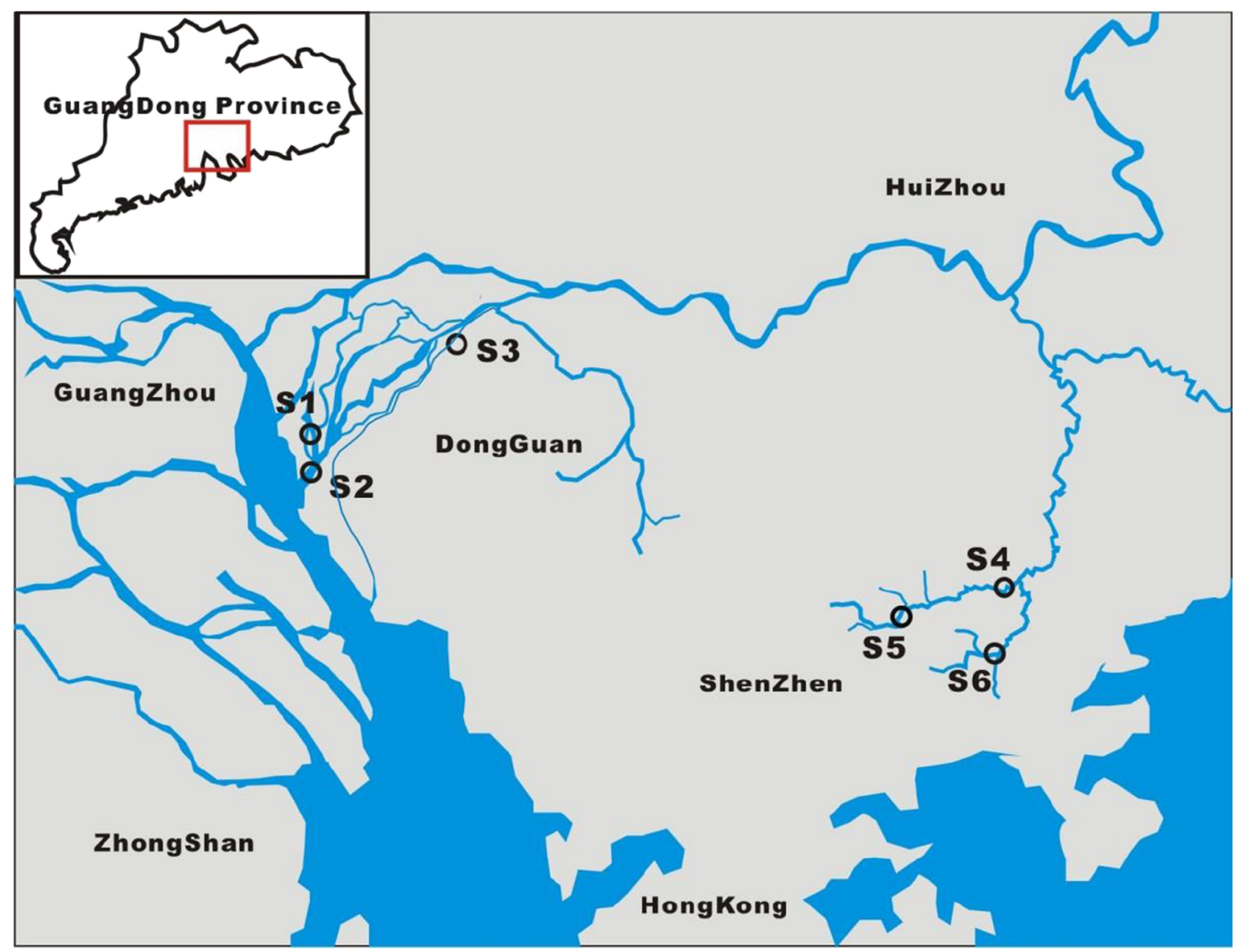

Fig. 1 The location of sampling sites

a mixed adsorbent column ( $8 \mathrm{~mm}$ inner diameter) containing $12 \mathrm{~cm}$ silica gel, $6 \mathrm{~cm}$ alumina, and $1 \mathrm{~cm}$ sodium sulfate from the bottom to the top. The column was successively eluted using $10 \mathrm{~mL}$ hexane, $70 \mathrm{~mL}$ of a mixture of hexane and DCM (7:3), and $60 \mathrm{~mL}$ of a mixture of hexane and acetone $(8: 2)$. The PAHs and OCPs were eluted in the second fraction, and the PAEs were eluted in the third fraction. The solvents in each fraction were removed by rotary evaporation and concentrated to $0.2 \mathrm{~mL}$ under a gentle stream of nitrogen. Known amounts of internal standards were spiked before the instrumental analyses. Twenty grams of sediment samples were spiked with the surrogate standards and Soxhlet-extracted with $200 \mathrm{~mL}$ DCM for $72 \mathrm{~h}$. The extract was treated by the same procedure as the DCM extract of the water samples. Finally, the fractionated samples were concentrated to $0.5 \mathrm{~mL}$ and spiked with a known amount of the internal standard for the quantification.

\section{Instrument analysis}

All the samples were analyzed using a 7890A gas chromatograph equipped with a $5975 \mathrm{C}$ mass spectrometer detector (Agilent Technologies, USA) and a HP-5MS silica fused capillary column $(30 \mathrm{~m} \times 250 \mu \mathrm{m} \times 0.25 \mu \mathrm{m})$, as described in our previous report ( $\mathrm{Li}$ et al. 2013). For the PAHs, the column temperature was programmed from 80 to $280{ }^{\circ} \mathrm{C}$ at a rate of $3{ }^{\circ} \mathrm{C} \mathrm{min}{ }^{-1}$ and to $300{ }^{\circ} \mathrm{C}$ at $10{ }^{\circ} \mathrm{C} \mathrm{min}{ }^{-1}$ and held there for $10 \mathrm{~min}$. For the OCPs, the temperature was initially held at $80{ }^{\circ} \mathrm{C}$ for $1 \mathrm{~min}$, raised to $140{ }^{\circ} \mathrm{C}$ at $15{ }^{\circ} \mathrm{C} \mathrm{min}{ }^{-1}$, then to $280{ }^{\circ} \mathrm{C}$ at $4{ }^{\circ} \mathrm{C} \mathrm{min}{ }^{-1}$, and finally to $300{ }^{\circ} \mathrm{C}$ at $10^{\circ} \mathrm{C} \mathrm{min}^{-1}$ for $10 \mathrm{~min}$. For the PAEs, the temperature was set at $80^{\circ} \mathrm{C}$ for $1 \mathrm{~min}$, raised to $180{ }^{\circ} \mathrm{C}$ at $10^{\circ} \mathrm{C} \mathrm{min}^{-1}$ and held there for $1 \mathrm{~min}$, then to $260{ }^{\circ} \mathrm{C}$ at $2{ }^{\circ} \mathrm{C} \mathrm{min}{ }^{-1}$, and finally to $300{ }^{\circ} \mathrm{C}$ at $10^{\circ} \mathrm{C} \mathrm{m^{-1 }}$ and held there for $10 \mathrm{~min}$. The temperatures of the GC injector inlet for PAHs, OCPs, and PAEs were 290, 250 , and $300{ }^{\circ} \mathrm{C}$, respectively, and the degradation of DDT was checked to be $11 \%$. The injection volume was $1 \mu \mathrm{L}$, and the data were acquired using a selected ion monitoring (SIM) mode.

The total organic carbon (TOC) of the sediment samples were determined using a CHNS elemental analyzer (Vario EL III Elementar, Germany), and the samples were soaked with a $10 \%(w / w)$ hydrochloric acid solution to remove the inorganic carbon before the analysis.

Quality control and quality assurance

The quantifications were performed as follows: The peak areas of the target compounds were normalized using internal 
standards and quantified using five-point calibration curves with $R^{2}$ values greater than 0.99 . Procedure and spiked blanks were conducted to determine the blank values and recoveries of the target compounds. The recoveries of the target compounds were defined as (concentration detected in spikeconcentration detected in blank)/concentration spiked. The recoveries of 15 PAHs (except naphthalene) were 60.1799.28 and $61.67-88.61 \%$ in the water and sediment samples, respectively. The recoveries of OCPs were 65.78-115.29 and $59.21-106.23 \%$ in the water and sediment samples, respectively. The recoveries of PAEs were 53.50-124.55 and 61.13$127.83 \%$ in the water and sediment samples, respectively. All the samples were spiked with known amounts of the surrogate standards before the extractions, and the average recoveries were $60-120 \%$ for all the surrogate standards, as shown in Table S2. The concentrations of the analytes reported in this work were not adjusted with the surrogate recoveries. The instrument detection limit (IDL) was defined as three times that of the standard deviation of seven analyses of the lowest level in the calibration curve, and the method detection limit (MDL) was calculated by using Eq. 1 as follows:

$\mathrm{MDL}=\frac{\mathrm{IDL} \times \text { Concentrated Volume }}{\text { Injected Volume } \times \text { Sample Volume }}$

where the concentrated volumes are 0.2 and $0.5 \mathrm{~mL}$ for the water and sediment samples, respectively; the injection volume is $1 \mu \mathrm{L}$; and the sampling volumes are $20 \mathrm{~L}$ and $20 \mathrm{~g}$ for the water and sediment samples, respectively. The MDLs in the water samples were $0.03-0.07,0.01-0.19$, and $0.03-$ $0.36 \mathrm{ng} / \mathrm{L}$ for the PAHs, OCPs, and PAEs, respectively, whereas the MDLs in the sediment samples were 0.07-0.17, $0.03-0.47$, and $0.01-0.90 \mathrm{ng} / \mathrm{g}$ for the PAHs, OCPs, and PAEs, respectively. The details are shown in Table S3.

\section{Phase partition of SVOCs}

The TOC normalized partition coefficient $\left(K_{\mathrm{oc}}\right)$ has been calculated to describe the partition process (Zeng et al. 1999) as follows:

$K_{\mathrm{oc}}=C_{\mathrm{s}} /\left(f_{\mathrm{oc}} C_{\mathrm{w}, \mathrm{e}}\right)$

where $C_{\mathrm{s}}(\mathrm{ng} / \mathrm{kg})$ is the $\mathrm{SVOC}$ concentration in the sediment samples, $f_{\text {oc }}$ is the fraction of the TOC in the sediment samples, and $C_{\mathrm{w}, \mathrm{e}}(\mathrm{ng} / \mathrm{kg})$ is the SVOC concentration in the water samples at the equilibrium state. The $K_{\text {oc }}$ values can be calculated from the octanol-water partition coefficients $\left(K_{\text {ow }}\right)$ by using an empirical equation (Schwarzenbach and Westall 1981) as follows: $\log K_{\mathrm{oc}}=0.72 \log K_{\mathrm{ow}}+0.49$. The ratio of $C_{\mathrm{w}, \mathrm{e}} / C_{\mathrm{w}}$ has been used to measure the tendency of SVOCs to partition into the water phase from the sediment (Zeng et al. 1999) as follows:

$\log \left(C_{\mathrm{w}, \mathrm{e}} / C_{\mathrm{w}}\right)=\log \left(C_{\mathrm{s}} / C_{\mathrm{w}}\right)-0.72 \log K_{\mathrm{ow}}-0.49-\log f_{\mathrm{oc}}$

where $C_{\mathrm{w}}(\mathrm{ng} / \mathrm{L})$ is the measured SVOC concentration in water. When $\log \left(C_{\mathrm{w}, \mathrm{e}} / C_{\mathrm{w}}\right)>0$, the detected concentration of SVOCs $\left(C_{\mathrm{w}}\right)$ in water was below the theoretical value at the equilibrium state $\left(C_{\mathrm{w}, \mathrm{e}}\right)$, and the transport of sedimentassociated SVOCs to water phase became thermodynamically achievable.

Human health risk assessment

The oral noncarcinogenic effect of the detected SVOCs through water consumption was assessed by noncarcinogenic hazard quotient (nHQ), which is defined as the ratio between the estimated daily intake (EDI) and the oral reference dose (RfD) given by the USEPA IRIS according to Eqs. 4 and 5:

$\mathrm{EDI}=\mathrm{Ci} \times \mathrm{CR} / \mathrm{BW}$

$\mathrm{nHQ}=\mathrm{EDI} / \mathrm{RfD}$

where $\mathrm{Ci}$ represents the concentration of the target contaminant, while the consumption rate (CR) of drinking water was set to be $2 \mathrm{~L} /$ day and the average body weight (BW) is $60 \mathrm{~kg}$ for Chinese adults. A nHQ $>1$ indicates a considerable hazard risk.

The cancer risk assessment of PAHs was conducted based on the margin of exposure (MOE) approach used by the European Food Safety Authority (EFSA) for PAH in food (EFSA 2005). This method was widely applied for cancer risk assessment of PAHs through dietary intake and water consumption (Benford et al. 2010; Blokker et al. 2013). MOE is calculated according to Eq. 6:

$\mathrm{MOE}=\mathrm{BMDL}_{10} / \mathrm{EDI}$

where the $\mathrm{BMDL}_{10}$ is the benchmark dose level of lower $95 \%$ confidence limit that is associated with $10 \%$ increase in cancer incidence in rodents. The MOEs of $\sum 8 \mathrm{PAHs}(\mathrm{B} a \mathrm{P}$, Chry, $\mathrm{B} a \mathrm{~A}, \mathrm{~B} b \mathrm{~F}, \mathrm{~B} k \mathrm{~F}, \mathrm{~B} g h i \mathrm{P}, \mathrm{D} i \mathrm{~B}, \operatorname{In} c d \mathrm{P})$ or $\sum 4 \mathrm{PAHs}(\mathrm{B} a \mathrm{P}$, Chry, $\mathrm{B} a \mathrm{~A}, \mathrm{~B} b \mathrm{~F}$ ) or $\sum 2 \mathrm{PAHs}$ (BaP, Chry) or $\mathrm{B} a \mathrm{P}$ alone were used by the EFSA to assess carcinogenicity, with specific BMDL $_{10}$ values of $0.49,0.34,0.17$, and $0.07 \mathrm{mg} / \mathrm{kg}(\mathrm{BW}) /$ day, respectively (EFSA 2008). And an MOE of $\geq 10,000$ would be of low concern from a public health point of view according to EFSA (EFSA 2005). To our knowledge the cancer risk of OCPs has seldom been assessed using the MOE method due to lack of available $\mathrm{BMDL}_{10}$ values. Thus, the cancer risk of OCPs was quantitatively assessed using the linear low-dose cancer risk equation according to USEPA's guidelines for carcinogen risk assessment (USEPA 2005), 
another generally accepted method (Wang et al. 2011; Zhou et al. 2012):

Cancer $\quad$ Risk $=$ EDI $\times$ Oral Slope Factor

The RfDs and oral slope factors can be accessed on the USEPA IRIS, and they were also listed in Table S4 for readers' reference. The risk lower than $10^{-6}$ is considered acceptable, and a value between $10^{-6}$ and $10^{-4}$ is of concern, while risk above $10^{-4}$ is unacceptable (USEPA 2005).

\section{Results and discussion}

Levels and congener profiles of SVOCs

\section{PAHS}

At all the six sampling sites, the concentrations of each PAH in the water and sediment samples during both seasons are listed in Table S5, and the distributions of the $\sum 15 \mathrm{PAHs}$ are shown in Fig. 2. In the water, the concentrations of $\sum 15$ PAHs were 2.0-47 and 13-48 $\mathrm{ng} / \mathrm{L}$ during the dry and wet seasons, respectively. The levels of $\sum 15$ PAHs in water during the wet season were usually higher than those during the dry season, except at S4 (Fig. 2a). Generally, the precipitation induces new input of contaminants by accelerating wet deposition of airborne particles and inflow of surface dusts or soils. At the same time, it would dilute the contaminants, especially during the wet season. Obviously, the new input was more predominant than the dilution effect in most of the sampling sites, indicating that nonpoint source pollution occurred in terms of
PAHs in this region. The dilution effect caused by the precipitation was responsible for the decrease in PAH concentration in the wet season at site $\mathrm{S} 4$ because this site was located at a less developed rural area. Sites S1 and S2 were located at the downstream of a drinking water source area; therefore, $\mathrm{PAH}$ levels were lower than the other sites. Site S3 was located at a canal which was used as a sewage discharge channel; therefore, the PAH level at site S3 was higher than those at sites S1 and S2, particularly in the wet season.

Compared with water samples, the concentrations of $\sum 15$ PAHs were much higher in the corresponding sediment samples, i.e., $29-1.1 \times 10^{3}$ and $33-1.2 \times 10^{3} \mathrm{ng} / \mathrm{g}$ during the dry and wet seasons, respectively (Table S5). Similar to those in water samples, the concentrations in sediment during the wet season were generally higher than during the dry season except at sites S1 and S4 (Fig. 2b). The concentration at site S6 was rather low because the river bed was mainly composed of sand particles with less organics. From the congener profiles of PAHs in all samples (Fig. 2), it can be seen that more than $70 \%$ of $\sum 15$ PAHs in water samples at all sites were PAHs with two and three aromatic rings, whereas three- and four-ring PAHs were more abundant in all sediment samples, which is consistent with a previous report (An et al. 2011).

Compared with other studies, where the sum of 15 identical PAH species with this study were extracted (Table S6), the total dissolved 15 PAH levels in this study $(2.0-47 \mathrm{ng} / \mathrm{L}$ in the dry season and 13-48 $\mathrm{ng} / \mathrm{L}$ the in wet season) were much lower than the Yellow River $\left(1.8 \times 10^{2}-3.7 \times 10^{2} \mathrm{ng} / \mathrm{L}\right.$ in 2004) (Li et al. 2006), Xijiang River $\left(22-1.4 \times 10^{2} \mathrm{ng} / \mathrm{L}\right.$ during 2003-2004) (Deng et al. 2006), Tonghui River $\left(1.5 \times 10^{2}-\right.$ $8.5 \times 10^{2} \mathrm{ng} / \mathrm{L}$ in 2002) (Zhang et al. 2004), and Qiantang River (70-1.8 $\times 10^{3} \mathrm{ng} / \mathrm{L}$ in 2005-2006) (Zhu et al. 2008); however, the levels were higher than Susquehanna River
Fig. 2 Concentrations and species composition of $\sum 15$ PAHs in a water and $\mathbf{b}$ sediment samples ( $D$ dry season, $W$ wet season)

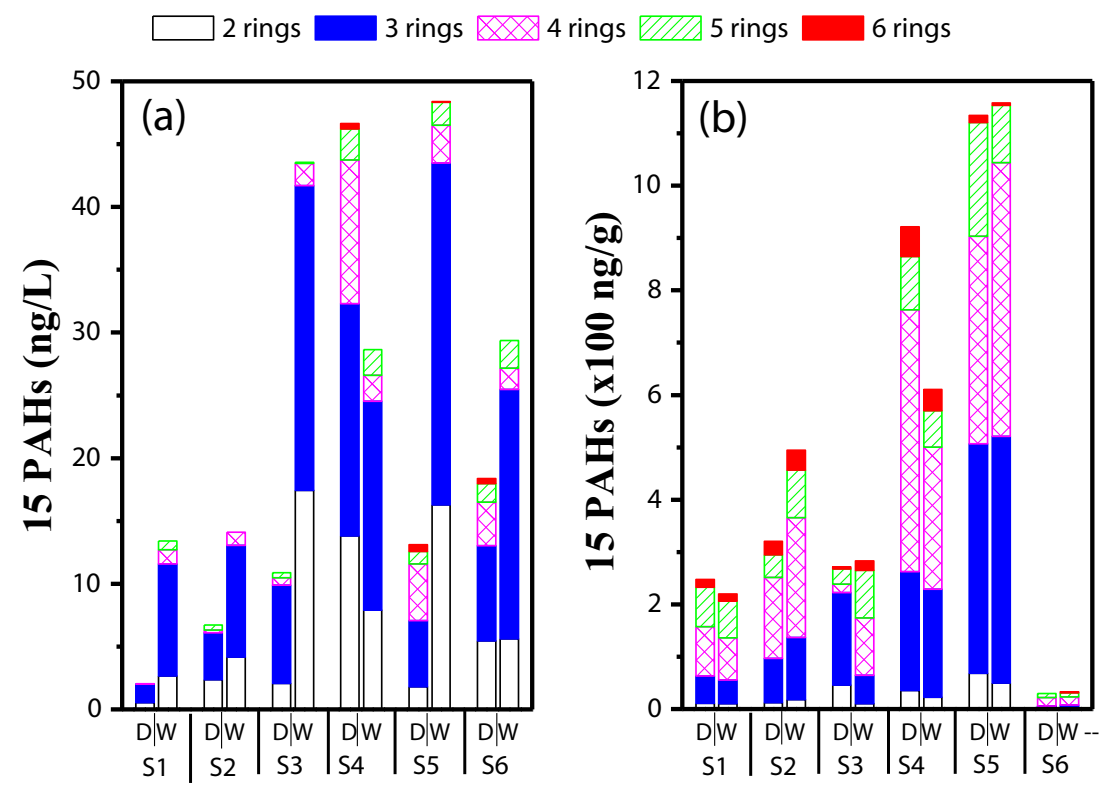


(13 ng/L in 1997-1998) (Ko and Baker 2004) and San Joaquin River $(<0.1-18 \mathrm{ng} / \mathrm{L}$ in 1992) (Pereira et al. 1996). The concentrations of PAHs in sediment samples in this study $\left(29-1.1 \times 10^{3} \mathrm{ng} / \mathrm{g}\right.$ in the dry season and $33-1.2 \times 10^{3} \mathrm{ng} / \mathrm{g}$ in the wet season) were close to that in Qiantang River (91-1.8 $\times$ $10^{3} \mathrm{ng} / \mathrm{g}$ in 2005-2006) and higher than those in Yellow River $\left(31-1.3 \times 10^{2} \mathrm{ng} / \mathrm{g}\right.$ in 2004) and San Joaquin River (4.2-7.7× $10^{2} \mathrm{ng} / \mathrm{g}$ in 1992). The different distribution trends of PAHs between water and sediment samples compared to other studies may indicate the nonequilibrium phase partition of PAHs in this study, which will be further discussed later.

\section{$O C P S$}

Concentrations of each OCP are listed in Table S7. The concentrations of dissolved $\sum 200 C P$ s were 6.6-57 and 17$27 \mathrm{ng} / \mathrm{L}$ during the dry and wet seasons, respectively. Sites S4, S5, and S6 demonstrated higher OCP levels than the other sites during the dry season, whereas the concentrations were rather close at all sites during the wet season (Fig. 3a). The contamination levels of $\sum 20 \mathrm{OCPs}$ were higher during the dry season than those during the wet season at sites $\mathrm{S} 4, \mathrm{~S} 5$, and S6, whereas an opposite trend was observed at sites S1, S2, and S3. The 20 individual OCPs can be divided into six groups such as $\mathrm{HCHs}(\alpha-\mathrm{HCH}, \beta-\mathrm{HCH}, \gamma-\mathrm{HCH}$, and $\delta$ HCH), DDTs (DDD, DDE, and DDT), chlordanes ( $\alpha$-chlordane and $\gamma$-chlordane), heptachlors (heptachlor and heptachlor epoxide), endosulfans ( $\alpha$-endosulfan, $\beta$-endosulfan, and endosulfan sulfate), and others (aldrin, dieldrin, endrin, endrin aldehyde, endrin ketone, and methoxychlor). Sites S1, S2, and S3 may have new input of OCPs during the wet season, particularly $\mathrm{HCHs}$ and endosulfans because their proportions in $\sum 200 C P$ s sharply increased during the wet season: HCHs (19-40, 29-48, and 29-75\% at sites S1, S2, and S3, respectively) and endosulfans (3.0-42, 6.6-34, and 14-21\% at sites $\mathrm{S} 1, \mathrm{~S} 2$, and $\mathrm{S} 3$, respectively).

In sediment, concentrations of $\sum 200 C P$ s were $10-4.5 \times 10^{2}$ and $9.3-6.0 \times 10^{2} \mathrm{ng} / \mathrm{g}$ during the dry and wet seasons, respectively (Table S7). As shown in Fig. 3b, the concentrations of $\sum 20$ OCPs at sites S3 and S4 were much higher than those in the other sites during the dry season. As mentioned earlier, site S3 is located near a canal, where large quantities of industrial and domestic sewage as well as sludge from a nearby wastewater treatment plant were disposed there since the 1990s. Therefore, the sediments accumulated over the years caused a higher level of $\sum 200 C P$ s at site 3, while the lower level of $\sum 200 C P$ at site S3 during the wet season was due to that the river had been dredged before this sampling. It is worth mentioning that the sewage was pretreated before being discharged into the canal after year 2007; therefore, the water phase at this site was less contaminated when our sampling was conducted during 2008-2009. The concentration at site S5 was extremely high compared to the other sites during the wet season. This is probably because many farmland fields are located along the riverside around site S5; the soils from the farmlands may have been eroded and taken into the river by the precipitation during the wet season. Site S6 contained sand-like sediments, resulting in a low level of $\sum 200 C P$ during both seasons. The composition profiles of the sediment samples were similar to those in the water samples with the $\mathrm{HCH}$ and endosulfans as the dominant groups. The HCHs were once used in large quantities for agriculture purposes in the PRD region. Some of them, particularly lindane for pest control and lice infestation therapies, were still in use till our sampling period. Endosulfan has been produced since 1994 in China; 100-500 t of endosulfan were used during 1994-2004 as either technical or formulated products within the Guangdong Province (Jia et al. 2009). Most of the
Fig. 3 Concentrations and species composition of $\sum 200 C P s$ in $\mathbf{a}$ water and $\mathbf{b}$ sediment samples ( $D$ dry season, $W$ wet season)

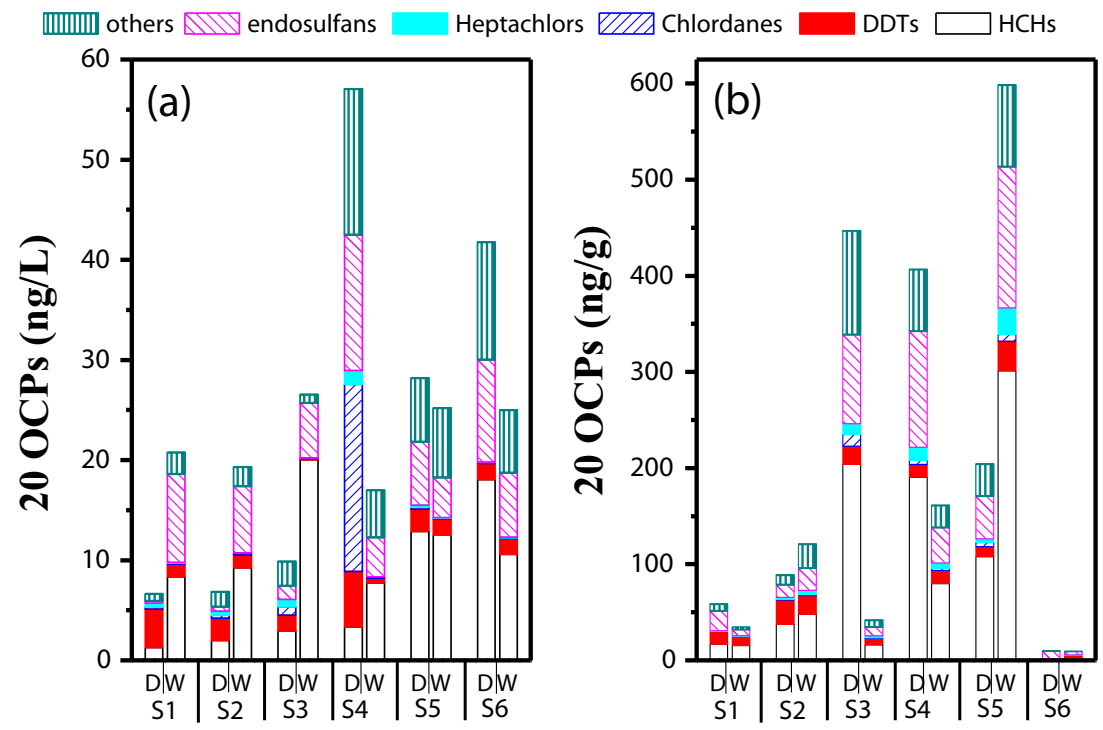


investigated areas in this study were urbanized or urbanizing on the previous agricultural land, and the commercial development possibly remobilized the previously buried HCHs and endosulfans (Fu et al. 2003).

The concentrations of $\mathrm{HCHs}$ (summation of $\alpha-\mathrm{HCH}, \beta-$ $\mathrm{HCH}, \gamma-\mathrm{HCH}$, and $\delta-\mathrm{HCH}$ ) and DDTs (summation of $p, p^{\prime}-$ DDT, $p, p^{\prime}$-DDD, and $p, p^{\prime}$-DDE) in this work were compared with other studies (Table S8). The concentrations of $\sum \mathrm{HCHs}$ in water during 2008 and 2009 in this work (1.3-18 ng/L in the dry season and 7.7-20 ng/L in the wet season) were lower than most of the reports, including Qiantang River (0.74-2.0 $\times$ $10^{2} \mathrm{ng} / \mathrm{L}$ in 2005) (Zhou et al. 2006) and Minjiang Estuary $\left(52-5.2 \times 10^{2} \mathrm{ng} / \mathrm{L}\right.$ in 1999) (Zhang et al. 2003) in China and Rivers of Northern Greece (nd to $2.3 \times 10^{2} \mathrm{ng} / \mathrm{L}$ in 1996 1998) (Golfinopoulos et al. 2003), close to those in Huaihe River, China (0.47-13 ng/L in 2007) (Feng et al. 2011). The dissolved concentration of $\sum D D T s$ in this study $(1.6-5.5 \mathrm{ng} / \mathrm{L}$ in the dry season and $0.47-1.6 \mathrm{ng} / \mathrm{L}$ in the wet season) was significantly lower than the reports mentioned above. Nevertheless, the pollution levels of $\sum \mathrm{HCH}$ in the sediment samples in this study $\left(0.94-2.0 \times 10^{2} \mathrm{ng} / \mathrm{g}\right.$ in the dry season and $2.6-3.0 \times 10^{2} \mathrm{ng} / \mathrm{g}$ in the wet season) were relatively higher than those in the abovementioned studies as well as those in CauBay River, Hanoi (4.6-11 ng/g in 2012) (Toan 2013). As to the level of $\sum$ DDTs in sediment samples, the results in this work $(0.29-25 \mathrm{ng} / \mathrm{g}$ in the dry season and $2.8-$ $31 \mathrm{ng} / \mathrm{g}$ in the wet season) were comparative with those in Qiantang River $\left(1.1-1.0 \times 10^{2} \mathrm{ng} / \mathrm{g}\right)$ and Minjiang River (1.6$13 \mathrm{ng} / \mathrm{g}$ ), but lower than those in GauBay River (52-93 ng/g), which may indicate different pollution characters and sources of HCHs and DDTs in China and Hanoi.

\section{PAES}

The concentrations of the individual PAEs (Table S9) and the distribution of the $\sum 15$ PAEs (Fig. 4) were also investigated. $\sum 15$ PAEs in the water were $9.2 \times 10^{2}-6.8 \times 10^{3}$ and $4.2 \times 10^{3}-$ $2.0 \times 10^{4} \mathrm{ng} / \mathrm{L}$ during the dry and wet seasons, respectively. In the water (Fig. 4a), higher concentrations of the $\sum 15$ PAEs were detected during the wet season than the dry season at all the sites, particularly at sites S4 and S5, because of precipitation-related new input. Site S4 was located at the downstream of site S5, where large quantities of domestic sewage and solid wastes were discharged into the river. The most abundant species in water were DiBP and DBP at sites S1, S2, and S3, while high levels of DEP were detected at sites S4, S5, and S6, particularly during the wet season.

In sediment, concentrations of $\sum 15 \mathrm{PAEs}$ were $1.6 \times 10^{3}-$ $1.8 \times 10^{5}$ and $8.9 \times 10^{2}-1.3 \times 10^{4} \mathrm{ng} / \mathrm{g}$ during the dry and wet seasons, respectively (Table S9). The PAE levels in sediment during the dry season were higher than those during the wet season, with peak values at sites S3 and S5 (Fig. 4b). Compared to water samples, DEHP was the dominant congener in sediment. PAEs with shorter side chains such as DiBP and DEP were more water soluble, whereas PAEs with longer side chains like DEHP were more lipophilic and mainly detected as adsorbed in sediment. The major PAEs detected in this study were comparable to the previous studies in the PRD region (Cai et al. 2007; Zeng et al. 2008).

The total levels of six dominant PAE species namely DMP, DEP, DiBP, DnBP, DEHP, and DOP were calculated in this study and compared with other regions (Table S10). PAE levels in water in this study $(0.87-6.6 \mu \mathrm{g} / \mathrm{L}$ in the dry season and $4.0-19 \mu \mathrm{g} / \mathrm{L}$ in the wet season) were lower than those in Yangtze River during the low water period $(36-91 \mu \mathrm{g} / \mathrm{L}$ in 2005) (Wang et al. 2008), but higher than those in Yangtze River in the high water period $(0.034-0.46 \mu \mathrm{g} / \mathrm{L})$ and Seine River estuary in France $(0.46-0.77 \mu \mathrm{g} / \mathrm{L}$ in $2005-2006)$ (Dargnat et al. 2009). The level of $\sum 6$ PAEs in sediment in this work $\left(1.6-1.8 \times 10^{2} \mu \mathrm{g} / \mathrm{g}\right.$ in the dry season and $0.86-$ $13 \mu \mathrm{g} / \mathrm{g}$ in the wet season) was lower than those in most studies, such as Gomti River in India $\left(0-3.6 \times 10^{2} \mu \mathrm{g} / \mathrm{g}\right.$ in 2008) (Srivastava et al. 2010) and the Wuhan section of Yangtze River during both low and high water periods (76$2.8 \times 10^{2} \mu \mathrm{g} / \mathrm{g}$ in the low water period and $1.5 \times 10^{2}-4.5 \times$ $10^{2} \mu \mathrm{g} / \mathrm{g}$ in the high water period, 2005) (Wang et al. 2008), but higher than those in Qiantang River $(1.9 \mu \mathrm{g} / \mathrm{g}$ in 2011) (Sun et al. 2013).

\section{Partitioning of SVOCs between water and sediment}

The plots of $\log \left(C_{\mathrm{w}, \mathrm{e}} / C_{\mathrm{w}}\right)$ versus $\log K_{\mathrm{ow}}$ are shown in Fig. 5. For all PAHs and most of OCPs, the calculated $\log \left(C_{\mathrm{w}, \mathrm{e}} / C_{\mathrm{w}}\right)$ values were positive during both seasons, indicating the analytes tended to dissolve into water from solids. PAHs and OCPs more probably originated from the deposition of airborne particles and inflow of dusts or soils. During the wet season, more particle- or soil-associated contaminants (mainly large molecules) were deposited into the river by precipitation and water flows, which increased the proportion of sedimentadsorbed PAHs and OCPs. As for PAEs, most of the $\log \left(C_{\mathrm{w}, \mathrm{e}}\right)$ $\left.C_{\mathrm{w}}\right)$ values were above the equilibrium line $\left(\log \left(C_{\mathrm{w}, \mathrm{e}} / C_{\mathrm{w}}\right)=0\right)$ during the dry season, whereas the majority of the values were below the equilibrium line during the wet season, indicating that PAEs would migrate from sediment into water during the dry season and partition from water into sediment during the wet season. Thus, new inputs of dissolved PAEs into the water phase during the wet season are possible, for example, through the dissolution of PAEs from various plastic materials by precipitation during the wet season.

\section{Sources of SVOCs}

The ratios of specific PAH isomers have been used to indicate the sources of PAHs (Yunker et al. 2002; Li et al. 2006; Jiang et al. 2009) (Table $\mathrm{S} 11)$. The $\mathrm{B} a \mathrm{~A} /(\mathrm{B} a \mathrm{~A}+$ Chry) and $\mathrm{In} c d \mathrm{P} /$ 
Fig. 4 Concentrations and species composition of $\sum 15$ PAEs in $\mathbf{a}$ water and $\mathbf{b}$ sediment samples ( $D$ dry season, $W$ wet season)

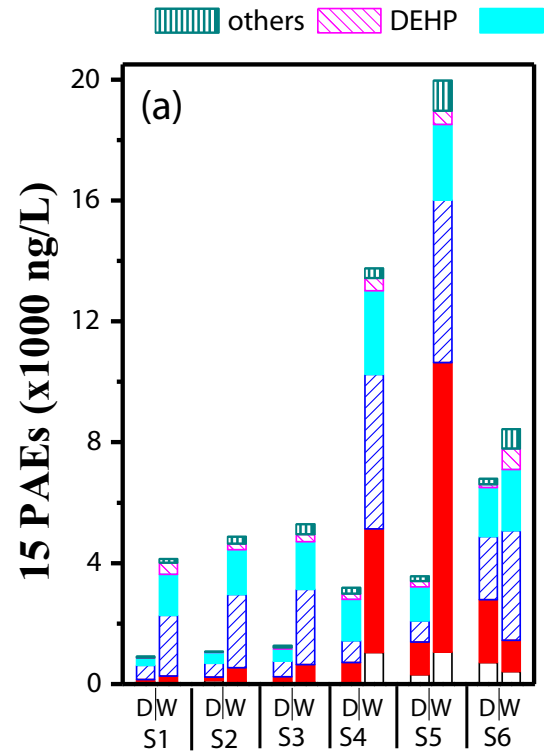

$(\mathrm{In} c d \mathrm{P}+\mathrm{B} g h i \mathrm{P})$ ratios were not calculated in water samples because these species were frequently not detected. Most of the sites except sites S5 and S6 during the dry season belonged to the region of Ant/(Ant+Phe) $>0.1$ and Flua/(Flua + Pyr $)>$ 0.5 (Fig. 6a), indicating biomass and coal combustion as the major sources for PAHs. In sediment, the major PAH source was petroleum combustion according to the Ant/(Ant+Phe) and Flua/(Flua + Pyr) ratios (Fig. 6b), and other mixed sources for PAHs were liquid petroleum combustion (vehicle emission) and grass, wood, or coal combustion according to the $\mathrm{B} a \mathrm{~A} /(\mathrm{B} a \mathrm{~A}+\mathrm{Chry})$ and $\mathrm{In} c d \mathrm{P} /(\mathrm{In} c d \mathrm{P}+\mathrm{BghiP})$ ratios (Fig. 6c). Generally, the combustions of petroleum products and coal were the major sources for PAHs in these studied areas. For example, several brickfields were located near sites S1 and S2, and various types of factories like tanyards, metal hardware factories, and paper mills existed around sites S5 and S6, where diesel and coal were burned. According to the local official survey of wastewater and pollutant discharges from the main companies during 2007, the annual discharged quantity of petroleum in wastewater was 18.43 tons (Liang 2008). Most of the wastewater was discharged into the canal where site S3 was located; therefore, the petroleum source was important at site S3.

Similar to PAHs, specific ratios of OCP isomers can be used to identify the possible sources (Table S12). In water (Fig. 7a), the proportions of $\beta-\mathrm{HCH}$ indicated no new $\mathrm{HCH}$ input at all sites during both seasons. The $\alpha-\mathrm{HCH} / \gamma-\mathrm{HCH}$ ratio indicated that $\mathrm{HCHs}$ detected in water mainly originated
Fig. 5 Plots of $\log \left(C_{\mathrm{w}, \mathrm{e}} / C_{\mathrm{w}}\right)$ versus $\log K_{\mathrm{ow}}$ for SVOCs, where data during the dry season are in black solid symbols and those during the wet season in red open symbols; PAHs in squares, OCPs in circles, and PAEs in $u p$ triangles

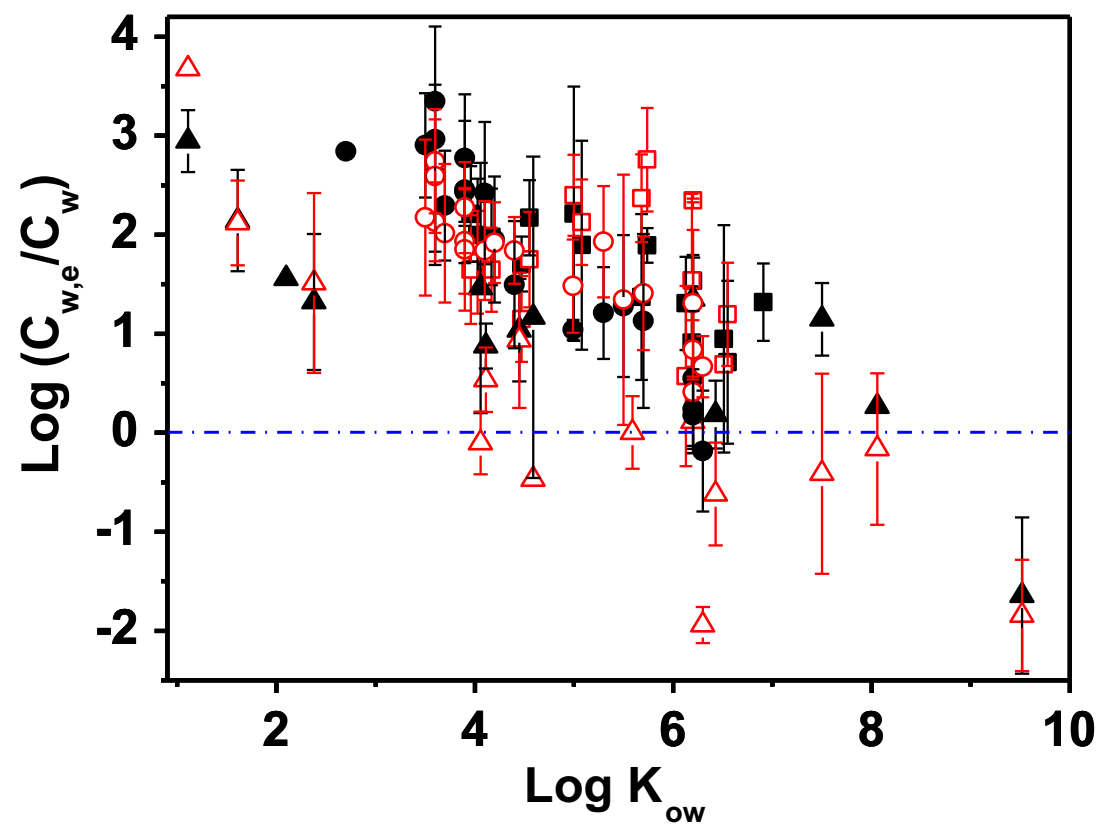


Fig. 6 Sources determination of PAHs in $\mathbf{a}$ water and $\mathbf{b}, \mathbf{c}$ sediment by different isomer ratios
Dry season $\diamond$ Wet season
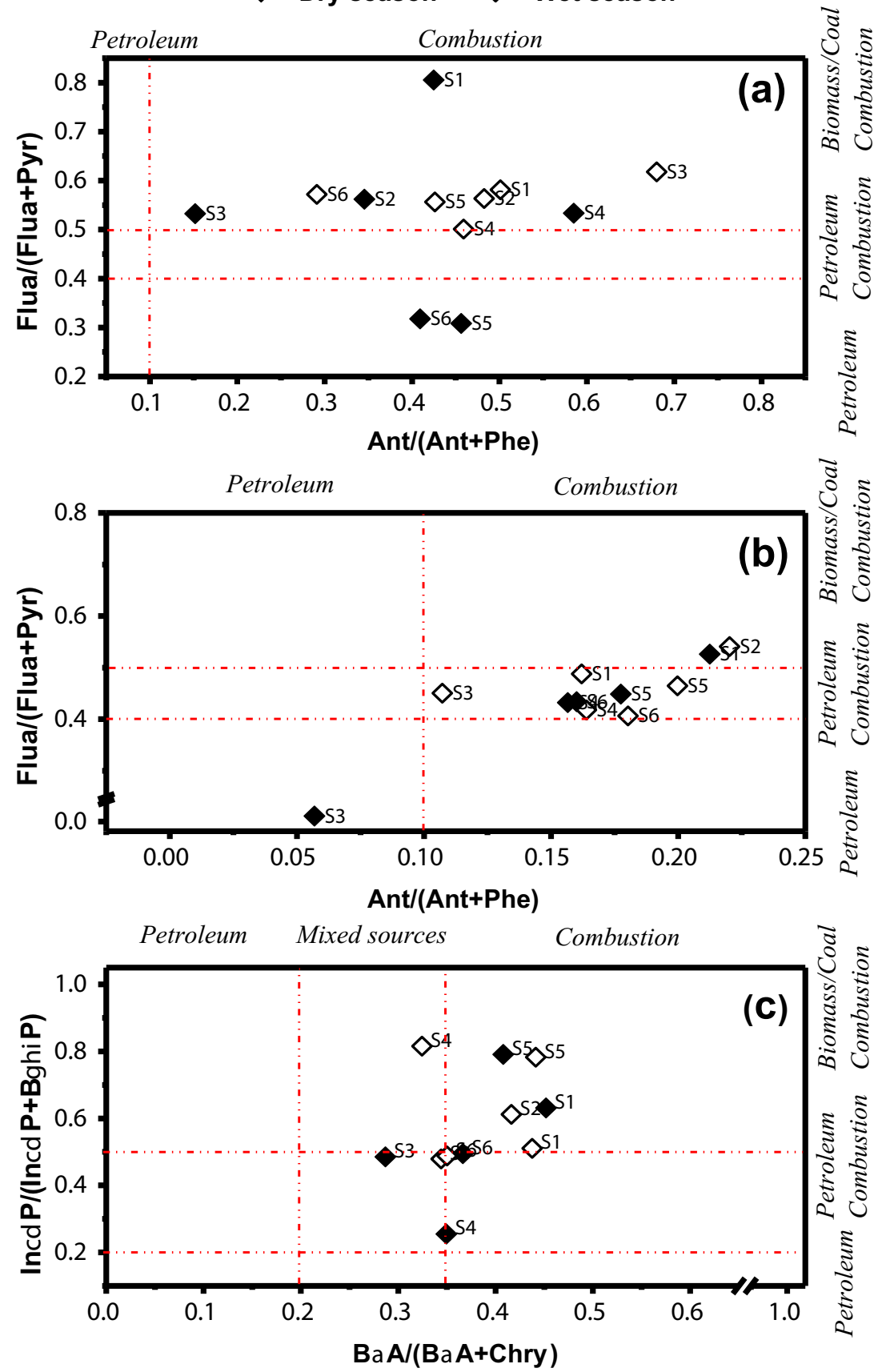

from the use of lindane except at site $\mathrm{S} 2$. In all sediment samples (Fig. 7b), the $\beta-\mathrm{HCH} / \mathrm{HCHs}$ ratios were more than $6 \%$, further confirming that $\mathrm{HCHs}$ originated from historical residue. The $\alpha-\mathrm{HCH} / \gamma-\mathrm{HCH}$ ratio in sediment showed that $\mathrm{HCHs}$ mainly originated from the use of lindane except at site S4 (during both seasons) and site S6 (during the wet season). The ratios of (DDD+DDE)/ 2 DDTs (Fig. S1) in the ESM 1 indicated probable new input of DDTs in most of water and sediment samples except in water at site S4 (during the dry season) and site S5 (during the wet season), as well as in sediment samples at site S3 (during the dry season) and site S2 (during the wet season). Fresh DDTs may be introduced by the application of technical DDTs for mosquito control, additive for antifouling paints for ships (Liu et al. 2009), and the production as well as the usage of dicofol (Qiao et al. 2010). The $\alpha$-chlordane $/ \gamma$-chlordane ratios were all less than 1 in water (Fig. S2a); however, the ratios were between 0.77 and 1 in sediment samples (Fig. S2b), indicating a mixture of historical residue ( $\alpha$-chlordane $/ \gamma$-chlordane $>1)$ and fresh input of technical chlordanes $(\alpha$-chlordane $/ \gamma$-chlordane $=0.77)$ before the sampling. Commercial technical endosulfan is a mixture of $\alpha$-endosulfan (70\%) and $\beta$-endosulfan (30\%) (Qiao 
Fig. 7 Compositions of $\mathrm{HCHs}$ and source determination in $\mathbf{a}$ water and $\mathbf{b}$ sediment

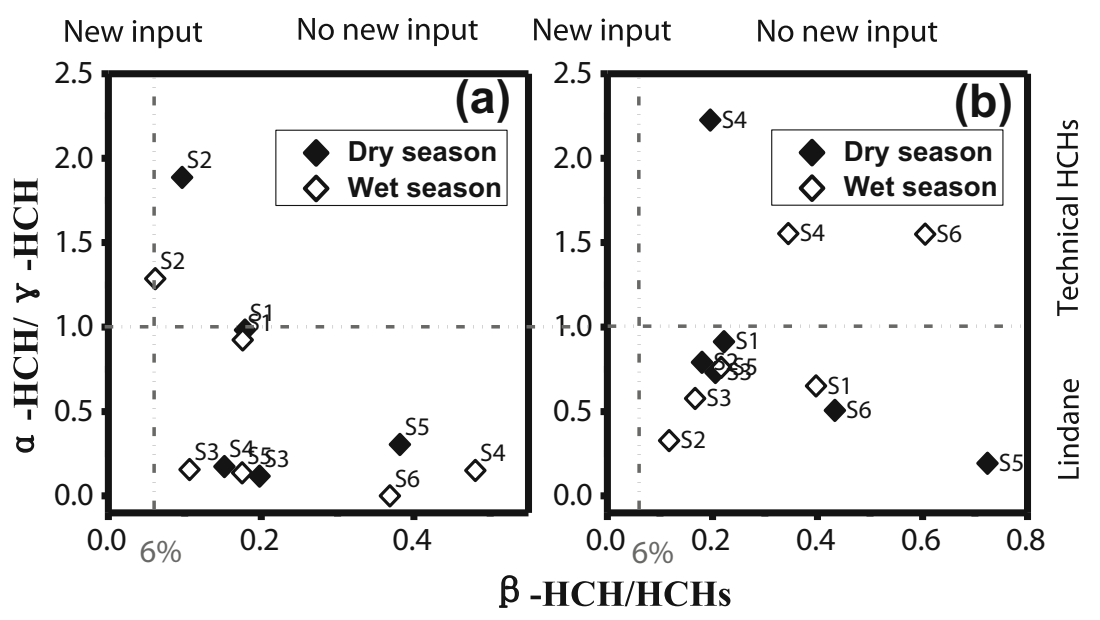

et al. 2010). Endosulfan sulfate is the metabolite of endosulfans and more recalcitrant (Kathpal et al. 1997). In water (Fig. 8a), the proportions of endosulfan sulfate were rather high, indicating the accumulation of the metabolite from historical application. Compared to the dry season, the metabolite proportion decreased during the wet season at sites S1 and S4, indicating possible inputs of fresh endosulfan. The proportions of endosulfan sulfate detected in sediment samples were lower than those in water sample during both seasons (Fig. 8b), probably due to better water solubility of endosulfan sulfate $\left(0.48 \mathrm{mg} / \mathrm{L}\right.$ at $\left.20^{\circ} \mathrm{C}\right)$ (Shiu et al. 1990) than endosulfan $(\alpha$-form $=0.32 \mathrm{mg} / \mathrm{L}, \beta$-form $=0.33 \mathrm{mg} / \mathrm{L}$ at $22{ }^{\circ} \mathrm{C}$ ) (Tomlin 1997). As mentioned, the most abundant PAE species in this work were DEP, DiBP, and DEHP. DEHP is the main PAE plasticizer in polyvinyl chloride resins owing to its low cost and excellent capacity to increase flexibility and transparency (Gomez-Hens and Aguilar-Caballos 2003; Rudel and Perovich 2009). DEP and DBP are widely used in cosmetic products, cellulose esters, print oils, and glues (Gomez-Hens and Aguilar-Caballos 2003). PAES are physically mixed into products without any chemical crosslinking; therefore, they can easily leak out particularly when the plastic is aged (Rakkestad et al. 2007). PAE levels at sites S5, S6 (industrial areas), and S4 (downstream of sites S5 and S6) were significantly higher than those at sites S1 and S2 (suburban areas), indicating that the industrial sewage was an important source for PAE contaminants. The abundance of DEP and DBP in water samples showed that domestic sewage containing various personal care products may also contribute to PAE pollution in the streams. Storm water runoff was another important source of PAEs, which was shown by the seasonal deviation of PAE levels in the water samples.

Human health risk assessment of SVOCs

Although the water from all the sites would not be drank by the residents directly in most of the cases, the health assessment through water consumption is a simple but effective
Fig. 8 Compositions of endosulfans in $\mathbf{a}$ water and $\mathbf{b}$ sediment (a)

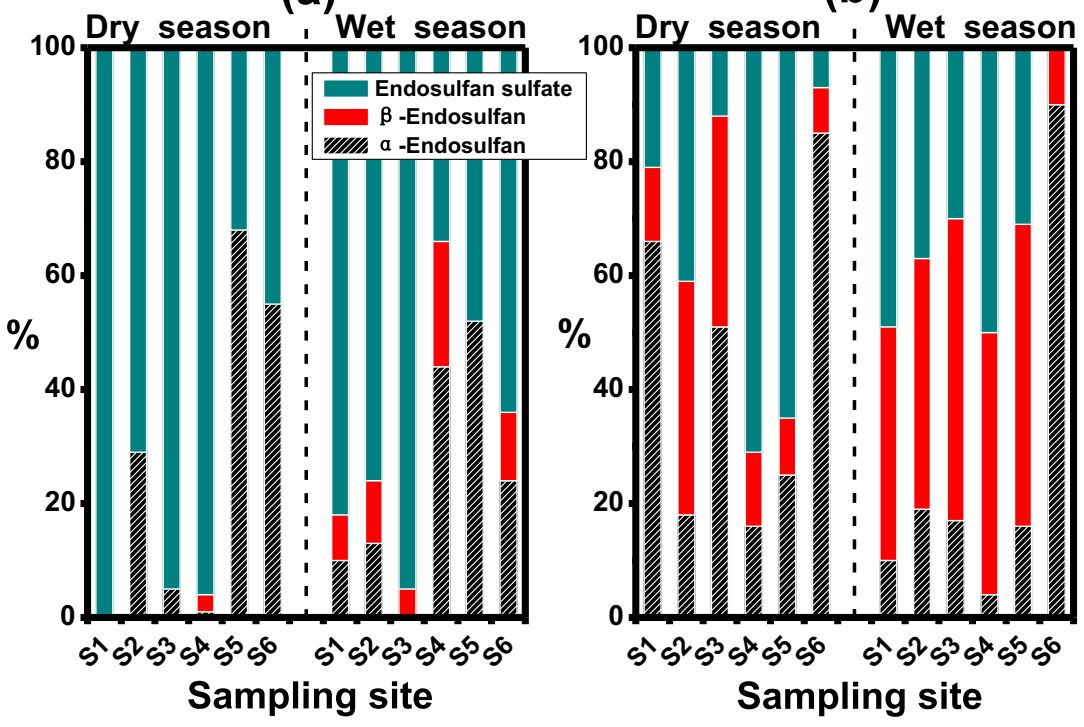


Table 1 Carcinogenic risk assessment of PAHs through water consumption using the margin of exposure (MOE) approach

\begin{tabular}{|c|c|c|c|c|c|c|}
\hline \multicolumn{3}{|c|}{$\begin{array}{l}\text { BMDL10 (mg/kg } \\
\text { body weight/day) }\end{array}$} & $\begin{array}{l}\sum 8 \mathrm{PAHs} \\
0.49\end{array}$ & $\begin{array}{l}\sum 4 \mathrm{PAHs} \\
0.34\end{array}$ & $\begin{array}{l}\sum 2 \mathrm{PAHs} \\
0.17\end{array}$ & $\begin{array}{l}\mathrm{B} a \mathrm{P} \\
0.07\end{array}$ \\
\hline \multirow[t]{12}{*}{ MOE } & Dry season & S1 & & & & \\
\hline & & S2 & $3.7 \mathrm{E}+07$ & $2.6 \mathrm{E}+07$ & $1.3 \mathrm{E}+07$ & $5.3 \mathrm{E}+06$ \\
\hline & & S3 & $2.1 \mathrm{E}+07$ & $2.7 \mathrm{E}+07$ & $1.3 \mathrm{E}+07$ & $5.5 \mathrm{E}+06$ \\
\hline & & S4 & $1.3 \mathrm{E}+06$ & $1.3 \mathrm{E}+06$ & $1.4 \mathrm{E}+06$ & $1.1 \mathrm{E}+06$ \\
\hline & & S5 & $4.2 \mathrm{E}+06$ & $5.4 \mathrm{E}+06$ & $5.5 \mathrm{E}+06$ & $5.8 \mathrm{E}+06$ \\
\hline & & S6 & $4.3 \mathrm{E}+06$ & $6.6 \mathrm{E}+06$ & $6.8 \mathrm{E}+06$ & $6.0 \mathrm{E}+06$ \\
\hline & Wet season & S1 & $1.2 \mathrm{E}+07$ & $2.0 \mathrm{E}+07$ & $5.8 \mathrm{E}+07$ & \\
\hline & & S2 & $3.3 \mathrm{E}+07$ & $2.3 \mathrm{E}+07$ & & \\
\hline & & S3 & $5.5 \mathrm{E}+07$ & $1.0 \mathrm{E}+08$ & & \\
\hline & & S4 & $6.2 \mathrm{E}+06$ & $5.1 \mathrm{E}+06$ & $2.7 \mathrm{E}+06$ & $1.2 \mathrm{E}+06$ \\
\hline & & S5 & $4.2 \mathrm{E}+06$ & $5.4 \mathrm{E}+06$ & $2.9 \mathrm{E}+06$ & $1.2 \mathrm{E}+06$ \\
\hline & & S6 & $5.6 \mathrm{E}+06$ & $5.2 \mathrm{E}+06$ & $2.7 \mathrm{E}+06$ & $1.2 \mathrm{E}+06$ \\
\hline
\end{tabular}

method to investigate the hazardous effects posed by the contaminants because these SVOCs (particularly OCPs) are rather persistent and may not be eliminated efficiently through conventional water treatment processes by the tap water suppliers. The noncarcinogenic hazard risks of SVOCs were evaluated (Figs. S3-S5 for PAHs, OCPs, and PAEs, respectively). The total nHQs of five PAHs with available RfD (Table S4) were far below 1 at all sites, indicating that no chronic health risk was posed by PAHs through water consumption. Similarly, the total nHQs of ten individual OCPs with oral RfD (Table S4) at all sites were below 1, indicating that OCPs would cause no noncancer hazard, either. As for PAEs, the nHQs were lower than 1 by three to four magnitudes, which suggested that the health risk was very low, even though PAE concentrations were quite high.
The carcinogenic risk of PAHs was assessed by means of the MOE approach and the results were listed in Table 1. It is obvious that all the MOE values at all sites were larger than 10,000 , no matter which PAH summation groups were used. And this suggests that the carcinogenic effect of PAHs in these sites would be of low concern. The cancer risks of OCPs shown in Fig. 9 suggested that the risks at sites S4-S6 during both seasons were higher than $10^{-6}$, the acceptable lifetime cancer risk suggested by USEPA, indicating that cancer risk through water consumption at these sites should not be neglected, though the risks were no more than $10^{-5}$. HCHs, dieldrin, and aldrin were the dominant carcinogens at these sites. Aldrin and dieldrin were widely used from the 1950s to the early 1970 s as an alternative to DDT (Zhang et al. 2012). Aldrin can breakdown to dieldrin in ecosystems; however, dieldrin is known to be resistant to bacterial and chemical degradation processes that leads to the accumulation of dieldrin in the environment (Tu et al. 1968). Additionally, among the 15 PAEs, only DEHP was classified as a possible carcinogen by the USEPA; therefore, the cancer risks of PAEs were not investigated in this study.

\section{Conclusion}

In this study, the levels of 50 SVOCs in the small rivers of the PRD region were investigated. Low levels of PAHs and OCPs were detected both in water and sediment samples, whereas slightly high levels of PAEs were detected with DBP, DiBP, and DEHP as the dominant congeners. The partition of SVOCs between water and sediment was absent from the equilibrium state, with PAHs and OCPs migrating from solid to water, whereas PAEs tended to move from water to
Fig. 9 Cancer risks posed by OCPs through drinking water intake by people in the PRD region during the a dry season and $\mathbf{b}$ wet season

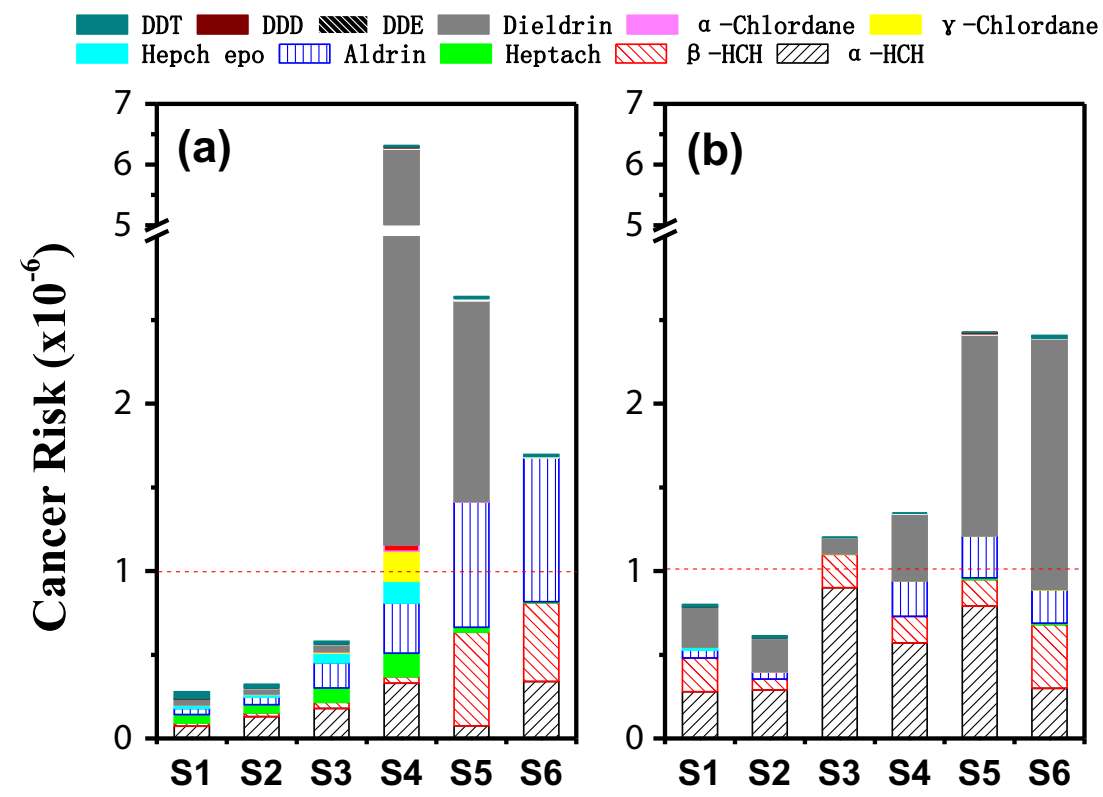


sediment. Source identification indicated that PAHs mainly originated from the combustion of petroleum and coal, whereas OCPs were historical residues except for chlordanes and DDTs. Although the detected SVOCs would pose no chronic health risk through daily water consumption according to our assessment, it may not be safe enough to drink the water directly because cancer risks did exist at several sites, and the risks from other water-soluble pollutants except for the determined SVOCs were not considered.

Acknowledgments This is contribution No. IS-1847 from GIGCAS. This work was financially supported by NSFC-Guangdong Joint Funds (No. U1201234) and the Science and Technology Project of Guangdong Province, China (2012A032300010).

\section{References}

An TC, Qiao M, Li GY, Sun HW, Zeng XY, Fu JM (2011) Distribution, sources, and potential toxicological significance of PAHs in drinking water sources within the Pearl River Delta. J Environ Monit 13: $1457-1463$

Benford D, Bolger PM, Carthew P, Coulet M, DiNovi M, Leblanc JC, Renwick AG, Setzer W, Schlatter J, Smith B, Slob W, Williams G, Wildemann T (2010) Application of the margin of exposure (MOE) approach to substances in food that are genotoxic and carcinogenic. Food Chem Toxicol 48(Supplement 1):S2-S24

Blokker EJM, van de Ven BM, de Jongh CM, Slaats PGG (2013) Health implications of $\mathrm{PAH}$ release from coated cast iron drinking water distribution systems in the Netherlands. Environ Health Perspect 121:600-606

Cai QY, Mo CH, Wu QT, Katsoyiannis A, Zeng QY (2008) The status of soil contamination by semivolatile organic chemicals (SVOCs) in China: a review. Sci Total Environ 389:209-224

Cai QY, Mo CH, Wu QT, Zeng QY, Katsoyiannis A (2007) Occurrence of organic contaminants in sewage sludges from eleven wastewater treatment plants, China. Chemosphere 68: $1751-1762$

Dargnat C, Blanchard M, Chevreuil M, Teil MJ (2009) Occurrence of phthalate esters in the Seine River estuary (France). Hydrol Process 23:1192-1201

Deng HM, Peng PA, Huang WL, Song HZ (2006) Distribution and loadings of polycyclic aromatic hydrocarbons in the Xijiang River in Guangdong, South China. Chemosphere 64:1401-1411

EFSA (2005) Opinion of the Scientific Committee on a request from EFSA related to a harmonised approach for risk assessment of substances which are both genotoxic and carcinogenic. EFSA J 282:1-31, Available at http://www.efsa.europa.eu/en/efsajournal/ doc/282.pdf

EFSA (2008) Polycyclic aromatic hydrocarbons in food. Scientific opinion of the panel on contaminants in the food chain. EFSA J 742:1114, Available at http://www.efsa.europa.eu/en/efsajournal/doc/724. pdf

Feng JL, Zhai MX, Liu Q, Sun JH, Guo JJ (2011) Residues of organochlorine pesticides (OCPs) in upper reach of the Huaihe River, East China. Ecotoxicol Environ Saf 74:2252-2259

Feng SL, Mai BX, Wei GJ, Wang XM (2012) Genotoxicity of the sediments collected from Pearl River in China and their polycyclic aromatic hydrocarbons (PAHs) and heavy metals. Environ Monit Assess 184:5651-5661

Fu, Mai BX, Sheng GY, Zhang G, Wang XM, Peng PA, Xiao XM, Ran R, Cheng FZ, Peng XZ, Wang ZS, Tang UW (2003) Persistent organic pollutants in environment of the Pearl River Delta, China: an overview. Chemosphere 52:1411-1422

Golfinopoulos SK, Nikolaou AD, Kostopoulou MN, Xilourgidis NK, Vagi MC, Lekkas DT (2003) Organochlorine pesticides in the surface waters of Northern, Greece. Chemosphere 50:507-516

Gomez-Hens A, Aguilar-Caballos MP (2003) Social and economic interest in the control of phthalic acid esters. TrAC Trend Anal Chem 22: 847-857

Guo LL, Qiu YW, Zhang G, Zheng GJ, Lam PKS, Li XD (2008) Levels and bioaccumulation of organochlorine pesticides (OCPs) and polybrominated diphenyl ethers (PBDEs) in fishes from the Pearl River estuary and Daya Bay, South China. Environ Pollut 152:604611

Jia H, Li YF, Wang D, Cai D, Yang M, Ma J, Hu J (2009) Endosulfan in China 1-gridded usage inventories. Environ Sci Pollut Res Int 16: 295-301

Jiang YF, Wang XT, Wang F, Jia Y, Wu MH, Sheng GY, Fu JM (2009) Levels, composition profiles and sources of polycyclic aromatic hydrocarbons in urban soil of Shanghai, China. Chemosphere 75: $1112-1118$

Jones KC, de Voogt P (1999) Persistent organic pollutants (POPs): state of the science. Environ Pollut 100:209-221

Kathpal TS, Singh A, Dhankhar JS, Singh G (1997) Fate of endosulfan in cotton soil under sub-tropical conditions of northern India. Pestic Sci 50:21-27

Ko FC, Baker JE (2004) Seasonal and annual loads of hydrophobic organic contaminants from the Susquehanna River basin to the Chesapeake Bay. Mar Pollut Bull 48:840-851

Li GC, Xia XH, Yang ZF, Wang R, Voulvoulis N (2006) Distribution and sources of polycyclic aromatic hydrocarbons in the middle and lower reaches of the Yellow River, China. Environ Pollut 144: 985-993

Li GY, Sun HW, Zhang ZY, An TC, Hu JF (2013) Distribution profile, health risk and elimination of model atmospheric SVOCs associated with a typical municipal garbage compressing station in Guangzhou, South China. Atmos Environ 76:173-180

Liang JF (2008) Research on current situation and control strategy of Dongguan river. Jinan University

Liu X, Zhang G, Li J, Yu LL, Xu Y, Li XD, Kobara Y, Jones KC (2009) Seasonal patterns and current sources of DDTs, chlordanes, hexachlorobenzene, and endosulfan in the atmosphere of 37 Chinese cities. Environ Sci Technol 43:1316-1321

Lohmann R, Breivik K, Dachs J, Muir D (2007) Global fate of POPs: current and future research directions. Environ Pollut 150:150-165

Pereira WE, Domagalski JL, Hostettler FD, Brown LR, Rapp JB (1996) Occurrence and accumulation of pesticides and organic contaminants in river sediment, water and clam tissues from the San Joaquin River and tributaries, California. Environ Toxicol Chem 15:172180

Qiao M, An TC, Zeng XY, Zhang DL, Li GY, Sheng GY, Fu JM, Zhang GX, Guo J (2010) Safety assessment of the source water within the Pearl River Delta on the aspect of organochlorine pesticides contamination. J Environ Monit 12:1666-1677

Rakkestad KE, Dye CJ, Yttri KE, Holme JA, Hongslo JK, Schwarze PE, Becher R (2007) Phthalate levels in Norwegian indoor air related to particle size fraction. J Environ Monit 9:1419-1425

Rudel RA, Perovich LJ (2009) Endocrine disrupting chemicals in indoor and outdoor air. Atmos Environ 43:170-181

Saillenfait AM, Sabate JP, Gallissot F (2008) Diisobutyl phthalate impairs the androgen-dependent reproductive development of the male rat. Reprod Toxicol 26:107-115

Schwarzenbach RP, Westall J (1981) Transport of non-polar organiccompounds from surface-water to groundwater-laboratory sorption studies. Environ Sci Technol 15:1360-1367

Shiu WY, Ma KC, Mackay D, Seiber JN, Wauchope RD (1990) Solubilities of pesticide chemicals in water part II: data compilation. 
In: Ware G, Niggs H, Bevenue A (eds) Reviews of environmental contamination and toxicology. Springer, New York, pp 15-187

Srivastava A, Sharma VP, Tripathi R, Kumar R, Patel DK, Mathur PK (2010) Occurrence of phthalic acid esters in Gomti River Sediment, India. Environ Monit Assess 169:397-406

Sun JQ, Huang J, Zhang AP, Liu WP, Cheng WW (2013) Occurrence of phthalate esters in sediments in Qiantang River, China and inference with urbanization and river flow regime. J Hazard Mater 248:142149

Toan VD (2013) Contamination of selected organochlorine pesticides (OCPs) in sediment from CauBay River, Hanoi. Bull Environ Contam Toxicol 90:132-135

Tomlin CDS (1997) The pesticide manual-world compendium, 11 th ed. British Crop Protection Council, Surrey, England

Tu CM, Miles JR, Harris CR (1968) Soil microbial degradation of aldrin. Life Sci 7:311-322

UNEP (2001) Final Act of the Plenipotentiaries on the Stockholm Convention on persistent organic pollutants. United Nations Environment Program Chemicals, Geneva, Switzerland, 445

USEPA, (2005) Guidelines for carcinogen risk assessment. Available at http://www.epa.gov/cancerguidelines/. Accessed 10 Mar 2014.

Wang F, Xia XH, Sha YJ (2008) Distribution of phthalic acid esters in Wuhan section of the Yangtze River, China. J Hazard Mater 154: $317-324$

Wang HS, Sthiannopkao S, Du J, Chen ZJ, Kim KW, Mohamed Yasin MS, Hashim JH, Wong CKC, Wong MH (2011) Daily intake and human risk assessment of organochlorine pesticides (OCPs) based on Cambodian market basket data. J Hazard Mater 192:1441-1449

Yunker MB, Macdonald RW, Vingarzan R, Mitchell RH, Goyette D, Sylvestre S (2002) PAHs in the Fraser River basin: a critical appraisal of PAH ratios as indicators of PAH source and composition. Org Geochem 33:489-515

Zeng EY, Yu CC, Tran K (1999) In situ measurements of chlorinated hydrocarbons in the water column off the Palos Verdes Peninsula, California. Environ Sci Technol 33:392-398

Zeng F, Cui KY, Xie ZY, Liu M, Li YJ, Lin YJ, Zeng ZX, Li FB (2008) Occurrence of phthalate esters in water and sediment of urban lakes in a subtropical city, Guangzhou, South China. Environ Int 34:372380

Zhang J, Liu F, Chen RB, Feng T, Dong SJ, Shen HQ (2012) Levels of polychlorinated biphenyls and organochlorine pesticides in edible shellfish from Xiamen (China) and estimation of human dietary intake. Food Chem Toxicol 50:4285-4291

Zhang ZL, Hong HS, Zhou JL, Huang J, Yu G (2003) Fate and assessment of persistent organic pollutants in water and sediment from Minjiang River Estuary, Southeast China. Chemosphere 52:14231430

Zhang ZL, Huang J, Yu G, Hong HS (2004) Occurrence of PAHs, PCBs and organochlorine pesticides in the Tonghui River of Beijing, China. Environ Pollut 130:249-261

Zhou P, Zhao Y, Li J, Wu G, Zhang L, Liu Q, Fan S, Yang X, Li $\mathrm{X}, \mathrm{Wu} \mathrm{Y}$ (2012) Dietary exposure to persistent organochlorine pesticides in 2007 Chinese total diet study. Environ Int 42:152-159

Zhou RB, Zhu LZ, Yang K, Chen YY (2006) Distribution of organochlorine pesticides in surface water and sediments from Qiantang River, East China. J Hazard Mater 137:68-75

Zhu LZ, Chen YY, Zhou RB (2008) Distribution of polycyclic aromatic hydrocarbons in water, sediment and soil in drinking water resource of Zhejiang Province, China. J Hazard Mater 150:308-316 